\title{
Considering the Effect of Rosa damascena Mill. Essential Oil on Oxidative Stress and COX-2 Gene Expression in the Liver of Septic Rats
}

\section{Rosa damascena Mill. Uçucu Yağının Sepsis Oluşturulmuş Sıçanların Karaciğerinde Oksidatif Stres ve COX-2 Gen Ekspresyonu Üzerine Etkilerinin Değerlendirilmesi}

\author{
(D) Abolfazl DADKHAH ${ }^{1 *}$, (D) Faezeh FATEMI2 , (D) Mohammad Reza Mohammadi MALAYERI ${ }^{3}$, (D) Mohammad Hassan Karvin ASHTIYANI 4 \\ (D) Sakineh Kazemi NOUREINI ${ }^{4}$, (D) Azadeh RASOOLI5 \\ 1/slamic Azad University, Qom Branch, Faculty of Medicine, Department of Medicine, Qom, Iran \\ 2Nuclear Science and Technology Research Institute, Materials and Nuclear Fuel Research School, Tehran, Iran \\ 3Islamic Azad University, Garmsar Branch, Faculty of Veterinary Medicine, Department of Pathobiology, Garmsar, Iran \\ 4 Hakim Sabzevari University, Faculty of Science, Department of Biology, Sabzevar, Iran \\ 5 Payame-e-Noor University, Faculty of Sciences, Department of Biochemistry, Tehran, Iran
}

\begin{abstract}
Objectives: Sepsis is a clinical illness with a high rate of mortality all over the world. Oxidative stress is considered the main phenomenon that occurs in sepsis. Rosa damascena Mill. is an ancient herbal plant with high pharmacological activities.

Materials and Methods: Cecal ligation and puncture (CLP) as a standard model was used to induce sepsis in rats. Male adult rats were randomly divided into 5 groups. Different doses of $R$. damascena essential oil (50 and $100 \mathrm{mg} / \mathrm{kg}$.bw) were gavaged orally for 14 days and on day 15 CLP was performed. After $24 \mathrm{~h}$, blood samples and liver tissues were removed in order to measure oxidative stress [myeloperoxidase (MPO), malondialdehyde (MDA), glutathione (GSH), glutathione-S-transferase, and ferric reducing ability of plasma (FRAP)] and biochemical parameters [alkaline phosphatase (ALP), aspartate transaminase (AST), alanine transaminase (ALT), and bilirubin] together with plasma prostaglandin $E_{2}$ $\left(P G E_{2}\right)$ and $\mathrm{COX}-2$ expression.

Results: The essential oil was capable of modulating all of the oxidative stress, antioxidant, and anti-inflammatory parameters induced by CLP as characterized by elevations in MPO and MDA levels as well as increases in AST and ALT concentrations concomitant with PGE ${ }_{2}$ and COX-2 increments. The antioxidant defense system such as GSH and FRAP was also increased in the essential oil treated groups.

Conclusion: Our results showed that the essential oil has antioxidative and hepatoprotective activities through reducing the oxidative injury in sepsis caused by CLP.
\end{abstract}

Key words: Sepsis, Rosa damascena Mill., oxidative stress, CLP, hepatoprotective activity

öz

Amaç: Sepsis, tüm dünyada yüksek ölüm oranına sahip klinik bir hastalıktır. Oksidatif stres sepsiste ortaya çıkan önemli bir olgu olarak kabul edilir. Rosa damascena Mill., farmakolojik aktiviteleri yüksek olan eski bir bitkidir.

Gereç ve Yöntemler: Standart bir model olarak çekal ligasyon ve ponksiyon (CLP), sıçanlarda sepsis oluşturmak için kullanılmıştır. Erkek yetişkin sıçanlar rastgele 5 gruba ayrılmıştır. $R$. damascena uçucu yağları (50 ve $100 \mathrm{mg} / \mathrm{kg}$ ) 14 gün boyunca oral yolla verilmiș ve 15 . günde CLP uygulanmıştır. Yirmi dört saat sonra, plazma plazma prostaglandin $E_{2}\left(P_{2} E_{2}\right.$ ) ve COX-2 ekspresyonu ile birlikte oksidatif stres (MPO, MDA, GSH, GST ve FRAP) ve biyokimyasal parametreleri [alkalen fosfataz, aspartate transaminase (AST), alanin transaminaz (ALT) ve bilirubin] ölçmek için kan örnekleri ve karaciğer dokuları çıkarılmıştır.

*Correspondence: E-mail: dadkhah_bio@yahoo.com, Phone: +989122490620 ORCID: orcid.org/0000-0001-6473-2233 Received: 29.04.2018, Accepted: 31.07.2018

๑Turk J Pharm Sci, Published by Galenos Publishing House. 
Bulgular: Uçucu yağ, MPO ve MDA seviyelerinde yükselme, PGE 2 ve COX-2 artışı, AST ve ALT konsantrasyonlarındaki artışla sonuçlanan CLPnedenli tüm oksidatif stres, antioksidan ve anti-enflamatuvar parametreleri düzenlemiştir. GSH ve FRAP gibi antioksidan savunma sistemi de uçucu yağ verilen gruplarda artmıştır.

Sonuç: Elde ettiğimiz sonuçlar, uçucu yağın, CLP'nin neden olduğu sepsiste oksidatif hasarı azaltarak antioksidan ve hepatoprotektif aktivitelere sahip olduğunu gösterdi.

Anahtar kelimeler: Sepsis, Rosa damascena, oksidatif stres, CLP, hepatoprotektif aktivite

\section{INTRODUCTION}

Sepsis is an ancient and serious clinical disease with high mortality in critically ill patients., ${ }^{1,2}$ Although all parasites and microorganisms have the potential to cause sepsis, the best known and most effective causes of pathogenesis of sepsis are Gram-negative and Gram-positive bacteria and fungi. ${ }^{3}$ Sepsis is the result of assaulting microbial pathogens or their products, like toxins in the bloodstream, expressed by the systemic inflammatory response to infection. ${ }^{4,5}$

In the initial stages of sepsis, a pathogenic microorganism stimulates the body to produce large amounts of chemokine and cytokines. ${ }^{6}$ The imbalance between pro-inflammatory and antiinflammatory parameters is responsible for the susceptibility to and outcome of sepsis. ${ }^{7}$ By increasing oxidative stress and reactive oxygen species (ROS), the body's antioxidant system is impaired, leading to effects on the cells and mitochondria and finally causing organ dysfunction. ${ }^{8}$

To investigate the pathogenesis of sepsis and its mechanisms, three methods are usually utilized: 1) injection and using lipopolysaccharides (LPS) and other exogenous toxin like zymogens; 2) applying different fatal and vivid pathogens; 3) elimination or changing the endogenous protective barrier, like cecal ligation and puncture (CLP) and colon ascendens stent peritonitis. ${ }^{9}$ All of them try to simulate pathophysiological changes, which are very similar to septic shock. ${ }^{10}$ Among them, CLP is the most accepted method to imitate human sepsis; it is considered a gold standard model. For the first time, Chaudhry in 1970 developed CLP among others." It is surgery involving cecum ligation and piercing, which can cause penetration microbial and pathogen factors, and finally causing sepsis. ${ }^{12}$

Due the increase of oxidant and inflammatory elements, a substitute for chemical drugs with high curative features and less side effects is noteworthy. ${ }^{13}$ The Damask rose (Rosa damascena Mill.) is an ancient herbal drug used for treatment of illnesses in the past. ${ }^{14}$ It belongs to the family Rosaceae, is considered an ornamental plant, and is known as the king of flowers. ${ }^{15}$ Nowadays, this plant is cultivated all over the world for its products, essential oil and rosewater. ${ }^{16}$

On the other hand, previous research has confirmed some pharmacological properties such as antioxidant, anti-HIV, and antibacterial activities. ${ }^{17}$ Different features of $R$. damascena were proposed in the distant past to cure bleeding and digestive problems and to treat abdominal pain in traditional medicine. ${ }^{16}$ Many studies have proved the antioxidant activity and other therapeutic effect of extract or essential oils of $R$. damascena. ${ }^{18,19}$ It was reported that hydroalcoholic extract of $R$. damascena has analgesic and anti-inflammatory effects by the formalin-induced method. ${ }^{13}$ The $R$. damascena essential oils as a natural antioxidant showed preventive effects against oxidative damage. ${ }^{20}$ However, there is no research on the therapeutic effect of $R$. damascena on hepatic injuries especially induced by sepsis. Thus, the present study was performed to evaluate the hepatoprotective and antioxidant activities of $R$. damascena essential oils against oxidative stress caused by CLP in the rat.

\section{MATERIALS AND METHODS}

\section{Essential oil extraction}

$R$. damascena essential oils were purchased from Barij Essence Pharmaceutical Co, Kashan Iran. A voucher specimen (Batch No: 714043, sample Serial No: AE932009) has been deposited at the Barij Essence company.

\section{GC and GC-mass analysis of Rosa damascena essential oils}

The $R$. damascena essential oils were qualitatively and quantitatively determined by GC of a Thermo Finnegan Trace GC (Thermo Electron, Waltham, MA, USA), consisting of an AI/ AS 3000 auto sampler equipped with a Thermo Finnegan Auto Mass quadruple mass spectrometer (Thermo Electron).

The GC analyzer was equipped with a TR5 fused silica column (30 m, $0.025 \mathrm{~mm}, 0.025 \mathrm{~m}$ coating thick). The analytical conditions were as follows: the column temperature was initiated at $50^{\circ} \mathrm{C}$ for $1 \mathrm{~min}$, then planned to rise to $280^{\circ} \mathrm{C}$ at a rate of $10^{\circ} \mathrm{C} / \mathrm{min}$ held by isothermal process. Helium was used as the carrier gas at the rate of $1.0 \mathrm{~mL} / \mathrm{min}$. Identification of the constituent was based on the comparison of $\mathrm{GC}$ retention with those stored in the Wiley mass spectra library.

\section{Free radical scavenging activity (DPPH assay)}

The radical scavenging activity of $R$. damascena essential oils was determined by DPPH assay. The absorbance of DPPH was read against the blank at $517 \mathrm{~nm}$. The inhibitory effect of the essential oils in percent ( $\%$ ) was calculated by the following equation:

\section{I $\%=($ Ablank-Asample/Ablank)×100}

\section{$\beta$-Carotene/linoleic acid bleaching assay}

To determine the antioxidant activity of $R$. damascena essential oils, the $\beta$-carotene/linoleic acid bleaching assay was performed. The oxidation of the $\beta$-carotene was monitored spectrophotometrically by measuring absorbance at $470 \mathrm{~nm}$ over $60 \mathrm{~min}$. The antioxidant activity of the essential oils was expressed as inhibition percentage with reference to the control after 60 min of incubation using the following equation:

$A A=100(D R C-D R S) / D R C$ 
where $\quad A A=$ antioxidant activity; $\quad D R C=$ degradation rate of control=[ $\ln (a / b) / 60] ; \quad D R S=$ degradation rate of sample $=[\ln (a / b) / 60] ; a=a b s o r b a n c e$ at time $0 ; b=a b s o r b a n c e$ at $60 \mathrm{~min}$.

\section{Treatment of animals}

Two-month-old male Wistar rats (200-250 g) were purchased from the animal breeding house of the Pasteur Institute, and were kept in the animal facility at the Qom Azad University animal room. The animals were acclimatized for 2 weeks in standard conditions and kept in a photoperiod of $12 \mathrm{~h}$ light/12 $\mathrm{h}$ dark at $20-25^{\circ} \mathrm{C}$. All the rats were fed a laboratory pellet diet and drinking water ad libitum.

The animals were divided into 5 groups $(n=10)$ : 1) Negative control (C): in the negative control group, dimethyl sulfoxide (DMSO), as solvent of essential oils, was orally administrated to the rats for 14 days following laparotomy surgery.

2) CLP group: as the control group, the rats received DMSO for 14 days following CLP surgery.

3 \& 4) CLP+R. damascena essential oils (50 and $100 \mathrm{mg} / \mathrm{kg}$ bw): the rats received orally essential oil of $R$. damascena once a day for 14 days dissolved in DMSO following CLP surgery.

5) $C L P+I N D(2 \mathrm{mg} / \mathrm{kg} \mathrm{bw}$ ): the rats were treated with indomethacin once a day for 14 days along with CLP.

\section{Sepsis induction}

Sepsis was induced by CLP. The rats were anesthetized by i.p. injection of ketamine and xylazine. Under sterile conditions, the cecum was exposed through a 1- to $2-\mathrm{cm}$ incision in the lower left abdomen, ligated on the ileocecal valve with 3-0 silk, and then was punctured twice with a 20 -gauge needle. The cecum was replaced in the peritoneum and the abdomen was closed with surgical staples. The rats were injected with $5 \mathrm{~mL}$ of saline s.c. for fluid resuscitation and were placed on a warming pad until they recovered from anesthesia.

\section{Preparation of tissue homogenate and plasma}

At $24 \mathrm{~h}$ after CLP induction, the rats in all groups were anesthetized with diethyl ether. Blood samples were withdrawn by heparinized syringe, followed by centrifugation at $3000 \times g$ for $10 \mathrm{~min}$. Plasma samples were collected and maintained at $-20^{\circ} \mathrm{C}$ for biochemical purposes. In addition, the liver tissues were removed and homogenized completely with buffer phosphate in an ice bath to evaluate oxidative stress biomarkers. A portion of that was also fixed in $10 \%$ formalin, for histopathological studies.

Determination of the oxidative stress and antioxidant parameters in the liver homogenate

\section{Glutathione (GSH) estimation}

The level of reduced GSH, as an antioxidant factor, was measured in liver homogenate as described by Sedlak and Lindsay. ${ }^{21}$ The GSH level in samples was calculated by plotting a standard curve of absorbance against different concentration of GSH standard solution.
Measurement of tissue myeloperoxidase (MPO) activity

The extent of neutrophil accumulation in the liver was evaluated by assaying MPO activity. MPO activity in the liver was measured by the procedure reported by Hillegass et al. ${ }^{22}$

\section{Measurement of tissue malondialdehyde (MDA)}

To investigate the rate of lipid peroxidation, the concentration of MDA was measured spectrophotometrically according the method of Buege and Aust. ${ }^{23}$

Measurement of tissue glutathione-S-transferase_(GST) activity GST activity was measured according to Habig et al. ${ }^{24}$ by investigating the conjugation of 1-chloro-2, 4-dinitrobenzene with reduced glutathione. The conjugation was done by an increase in the absorbance at $340 \mathrm{~nm}$.

\section{Ferric reducing ability of plasma (FRAP)}

The total antioxidant activity of plasma was measured by FRAP assay based on the Benzie method. ${ }^{25}$ According to this, at low $\mathrm{pH}$, ferric tripyridyltriazine_complex $\left(\mathrm{Fe}_{3}-\mathrm{TPTZ}\right)$ is reduced to the ferrous $\left(\mathrm{Fe}_{2}\right)$ form. In this reaction, an intense blue color is created with absorption at $593 \mathrm{~nm}$.

\section{Determination of prostaglandin $E_{2}\left(P G E_{2}\right)$ concentration}

$\mathrm{PGE}_{2}$ was assessed by ELISA kit (BioAssay System) according to the kit's instructions.

Determination of COX-2 gene expression using quantitative real time-polymerase chain reaction (RT-PCR)

Total RNA extracted from the rat livers, by RNA total kit (BioBasic Inc, Canada), was surveyed quantifiably by Nano Drop 2000. Then to synthetic cDNA, each sample was reverse transcribed into compulsory DNA (cDNA), using a PrimeScript ${ }^{\mathrm{tm}} \mathrm{RT}$ reg Kit (TaKaRa and oligo dt primers). The cDNA was stored at $-20^{\circ} \mathrm{C}$ until use.

In order to use specific primers of COX-2, Gene Runner software version 3.05 and primer 3 servers were applied.

Expression of COX-2 genes was investigated by real-time PCR system (Rotor-Gene Q-QIAGEN). The RT-PCR analyses were done using SYBER green real-time PCR Master Mix. The reaction compositions were Taq polymerase, dNTP, $\mathrm{MgCl}_{2}$, SYBER green I dye, $0.2 \mu \mathrm{L}$ of primers, $0.5 \mu \mathrm{L}$ of cDNA, and 10 $\mu \mathrm{L}$ of $\mathrm{H}_{2} \mathrm{O}$. The reaction condition was designed by an initial degeneration stage at $95^{\circ} \mathrm{C}$ for $2 \mathrm{~min}, 40$ cycles at $95^{\circ} \mathrm{C}$ for $15 \mathrm{~s}, 60^{\circ} \mathrm{C}$ for $20 \mathrm{~s}$, and then held $72^{\circ} \mathrm{C}$ for $20 \mathrm{~s}$. Each sample was measured in triplicate. At the completion of each run, melting curves for the amplicons were measured by raising the temperature by $0.3^{\circ} \mathrm{C}$ from 57 to $95^{\circ} \mathrm{C}$ while monitoring fluorescence. The comparative cycle threshold $\mathrm{Ct}$ method was used for the relative quantification of gene expression. Evaluation of the relative expression of mRNA was done and normalized to GAPDH reported as a housekeeping gene.

\section{Assessment of liver injury parameters}

To determine the functional injuries to the liver caused by polymicrobial sepsis, the plasma levels of alanine transaminase $(A L T)$, aspartate transaminase (AST), alkaline phosphatase 
(ALP), and total bilirubin were evaluated by Pars Azmoon kit (Iran).

\section{Histological analysis}

Tissue samples were fixed with $10 \%$ buffered formaldehyde, dehydrated, and embedded in paraffin. A liver section $(5 \mu \mathrm{m})$ was stained with hematoxylin and eosin and examined under light microscopy (Olympus CX31RBSF) to assess the hepatic changes.

Quantitative and semiquantitative histological analysis was also used for scoring the histopathological variables by a veterinary pathologist. The mean numbers of marginated and infiltrated neutrophils were counted in 10 random high power fields of the microscope. Thereafter, scoring was performed between 0 and 4 as follows: score $0=0$ up to 9 neutrophils, score 1=10 up to 19 neutrophils, score $2=20$ up to 29 neutrophils, score $3=30$ up to 39 neutrophils, score $4=$ more than 40 neutrophils. In addition, mononuclear cell infiltrations and Kupffer cell hyperplasia scoring were as follows: score $0=$ normal condition, score $1=$ mild changes, score $2=$ average changes, score $3=$ severe changes, score $4=$ more severe changes.

\section{Statistical analysis}

The data of this study were analyzed statistically with SPSS v.19. The data were expressed as mean \pm standard deviation. One-way analysis of variance was applied to compare the mean values. The significance was considered as $p$ value $<0.05$.

\section{RESULTS}

\section{Essential oil analysis and antioxidant activities}

As a result of the GC and GC-mass analysis, 24 chemical components were identified. The major constituents of $R$. damascena essential oils were characterized which were citronellol (66.11\%), trans-geraniol (11.56\%), phenylethyl alcohol (5.33\%), and other constituents such as linalool, pinene, citral, methyl eugenol, and geranene, presented in Table 1.

The DPPH and $\beta$-carotene-linoleic acid bleaching assays were used to evaluate the antioxidant activities of $R$. damascena essential oils. Essential oil was capable of reducing the concentration of DPPH free radicals, which was higher compared to Trolex (Figure 1). In addition, the $\beta$-carotenelinoleic acid bleaching test showed high antioxidant activity in comparison with the positive control (BHT) (Figure 2).
The effect of $R$. damascena essential oil on the oxidative stress and antioxidant parameters

According to the data presented in Table 2, hepatic GSH level was decreased due to CLP ( $p<0.05$ ). Accordingly, similar to the indomethacin treated group, $R$. damascena essential oils (50 and $100 \mathrm{mg} / \mathrm{kg}$ bw) followed by CLP increased the level of GSH to reach the level in the control group ( $p<0.05$ ).

\begin{tabular}{|c|c|c|c|}
\hline & Compound & Percentage & RI \\
\hline 1 & $\alpha$-Pinene & 1.81 & 920.967742 \\
\hline 2 & Sabinene & 0.08 & 953.225806 \\
\hline 3 & $\beta$-Pinene & 0.3 & 956.989247 \\
\hline 4 & Myrcene & 0.36 & 965.591398 \\
\hline 5 & Linalool & 1.42 & 1056.45161 \\
\hline 6 & Rose oxide (Isomer) & 0.47 & 1065.5914 \\
\hline 7 & Phenylethyl alcohol & 5.33 & 1072.04301 \\
\hline 8 & Rose oxide (Isomer) & 0.22 & 1079.56989 \\
\hline 9 & Citronellol & 66.11 & 1162.84153 \\
\hline 10 & Carvone & 0.76 & 1176.50273 \\
\hline 11 & Trans Geraniol & 11.56 & 1181.42077 \\
\hline 12 & Citral & 1.11 & 1194.53552 \\
\hline 13 & Citronellol acetate & 0.69 & 1252.40964 \\
\hline 14 & Eugenol & 0.83 & 1263.25301 \\
\hline 15 & Nerol acetate & 0.89 & 1277.71084 \\
\hline 16 & Methyl eugenol & 2.36 & 1297.59036 \\
\hline 17 & Caryophyllene (isomer) & 0.69 & 1315.06024 \\
\hline 18 & a-Guaiene & 0.54 & 1326.50602 \\
\hline 19 & Caryophyllene (isomer) & 0.52 & 1340.96386 \\
\hline 20 & Germacrene & 1.44 & 1362.04819 \\
\hline 21 & Bisabolene & 0.25 & 1373.49398 \\
\hline 22 & Bulenensene & 0.41 & 1378.31325 \\
\hline 23 & Tetradecane & 1.41 & 1510.13514 \\
\hline 24 & Farnesol & 0.45 & 1534.45946 \\
\hline
\end{tabular}

\section{Table 2. Effect of $R$. damascena essential oil on oxidative stress parameters}

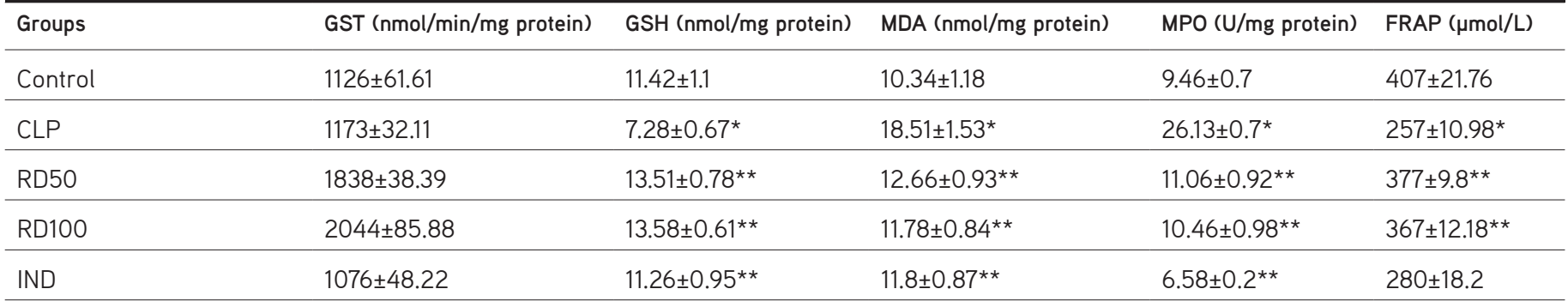

${ }^{*}$ p $<0.05$ is considered significant between the control group and cecal ligation and puncture group. ${ }^{\star *} p<0.05$ is considered significant between the cecal ligation and puncture group and treated groups. Data are presented as mean \pm standard deviation

CLP: Cecal ligation and puncture, IND: Indomethacin 
CLP induced significant increases in MPO activity as compared to the control group ( $p<0.05)$. On the other hand, decreases in MPO activity were seen in both groups treated by $R$. damascena essential oils (50 and $100 \mathrm{mg} / \mathrm{kg}$ bw) ( $p<0.05$ ) as shown in the indomethacin group (Table 2).

Hepatic MDA level was significantly evaluated as an indicator of lipid peroxidation in the CLP group in comparison to the control group ( $p<0.05$, Table 2). Treatment of rats with the essential oils significantly decreased the level of MDA in the liver ( $p<0.05$, Table 2)

Concerning the effect of sepsis on FRAP level (Table 2), CLP caused a significant decrease in FRAP level in comparison to the control group ( $p<0.05$ ). In addition, treatment of rats with $R$. damascena essential oils in doses of 50 and $100 \mathrm{mg} / \mathrm{kg}$ bw increased the level of FRAP to the ideal condition ( $p<0.05$, Table 2).

CLP did not change the GST activity (Table 2), but treatment of rats with 50 and $100 \mathrm{mg} / \mathrm{kg}$ bw of $R$. damascena essential oils increased the activity of GST compared to the control and CLP groups ( $p<0.05)$.

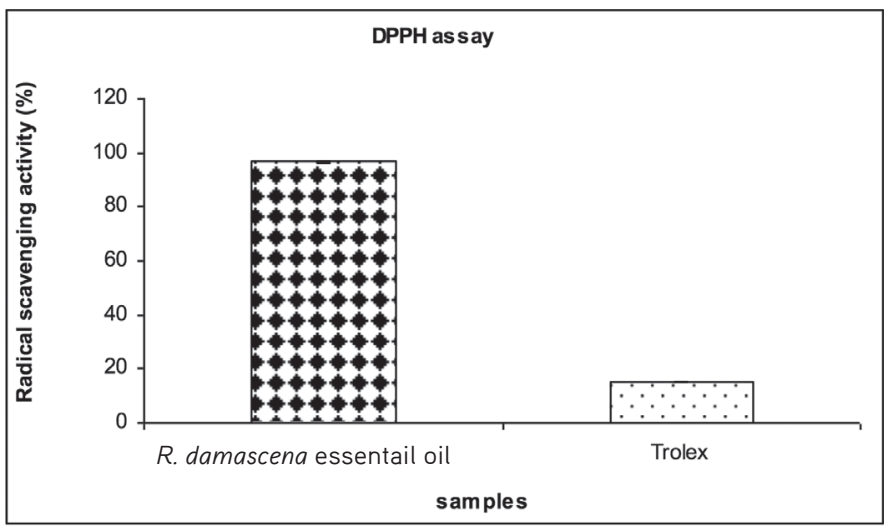

Figure 1. DPPH radical-scavenging activity of $R$. damascena essential oil. The different letters are significantly different at the $p<0.05$ level. Samples were done in triplicate $(n=3)$

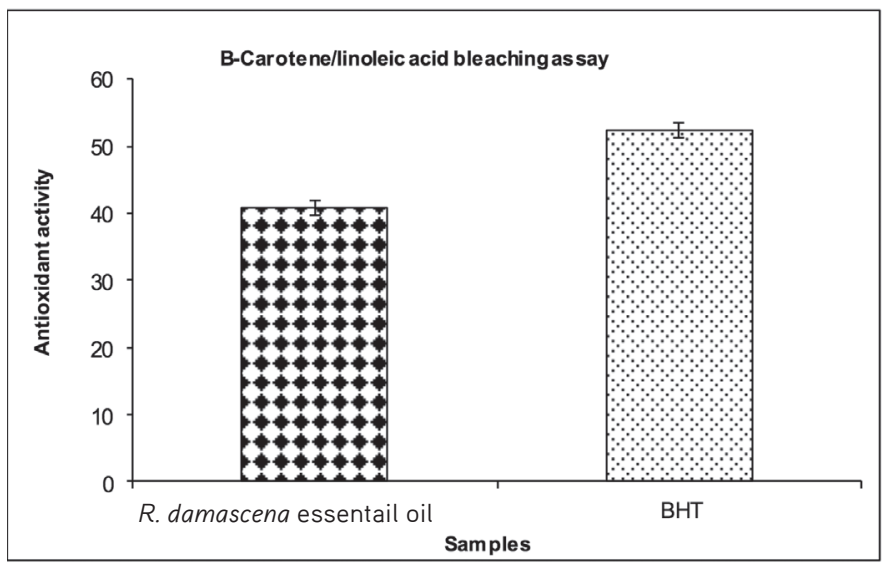

Figure 2. $\beta$-Carotene/linoleic acid bleaching assay of $R$. damascena essential oil. The different letters are significantly different at the $p<0.05$ level. Samples were done in triplicate $(n=3)$
$R$. damascena essential oils inhibited CLP-induced concentration of $P G$ - $_{2}$

In the present study, the evaluation of $\mathrm{PGE}_{2}$ concentration clearly indicated that CLP caused a significant increase in plasma level of $\mathrm{PGE}_{2}$ as compared to the control group ( $p<0.05$, Table 3). On the contrary, treatment of rats with $R$. damascena essential oils (50 and $100 \mathrm{mg} / \mathrm{kg}$ bw) significantly decreased plasma $\mathrm{PGE}_{2}$ concentration in comparison to the CLP group (p<0.05).

\section{$R$. damascena essential oil inhibited CLP-induced expression of $\mathrm{COX}-2$}

Table 3 shows the alteration of COX-2 expression in the different groups. The rats which received CLP showed a significant increase $(p<0.05)$ in COX-2 expression as compared to the control group. On the contrary, the rats that received $R$. damascena essential oils in 50 and $100 \mathrm{mg} / \mathrm{kg}$ bw followed by CLP had higher levels of COX-2 expression ( $p<0.05$, Table 3 ), which were also seen in indomethacin treated group, their levels were lower than the CLP group.

The effect of $R$. damascena essential oils on plasma biomarker for liver injuries

As shown in Figure 3, the plasma levels of AST and ALT significantly increased ( $p<0.05$ ) in the CLP group in comparison with the control group (Figures $3 \mathrm{~A}$ and $\mathrm{B}$ ), but, after treatment with the essential oils in doses of 50 and $100 \mathrm{mg} / \mathrm{kg}$ bw, the
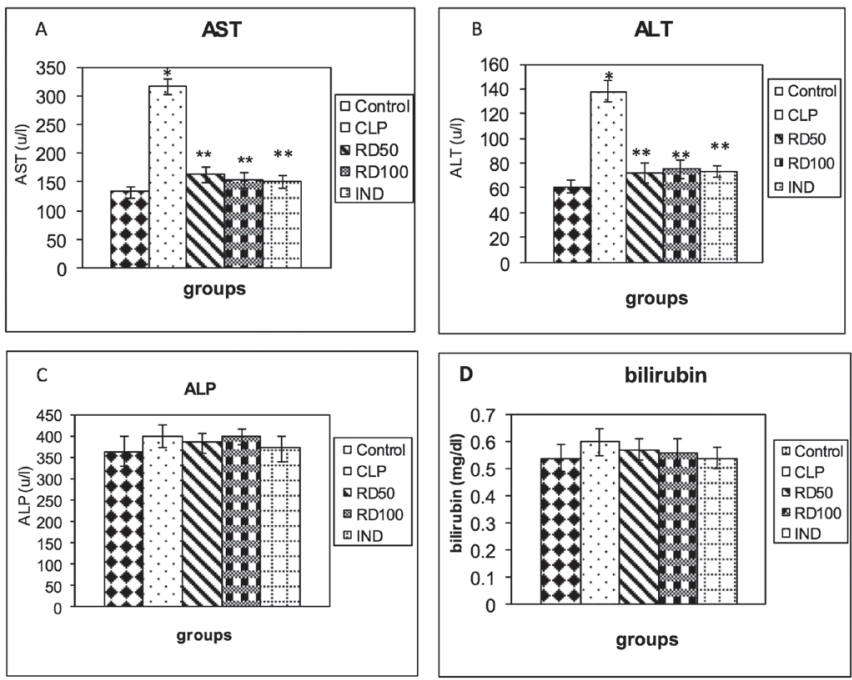

Figure 3. A) concentration of aspartate transaminase in different groups; B) concentration of alanine transaminase in different groups; $\mathrm{C}$ ) concentration of alkaline phosphatase in different groups; D) concentration of bilirubin in different groups. In the control group the rats underwent just laparotomy after 14 days administering DMSO orally. In the cecal ligation and puncture (CLP) group the animals received just DMSO for 14 days. RD50 and RD100 essential oil ( 50 and $100 \mathrm{mg} / \mathrm{kg}$ bw) was administered orally in 14 days and CLP was done. IND, treated as CLP group, with the difference that the rats received indomethacin orally incubation. Values represent mean \pm SD of the each group: ${ }^{*} p 0.05$ is considered significantly different from the control group within each parameter. ${ }^{*} p<0.05$ is considered significantly different from the CLP group within each parameter

RD: Rosa damascena ALT: Alanine transaminase, AST: Aspartate transaminase, ALP: Alkaline phosphatase, CLP: Cecal ligation and puncture 


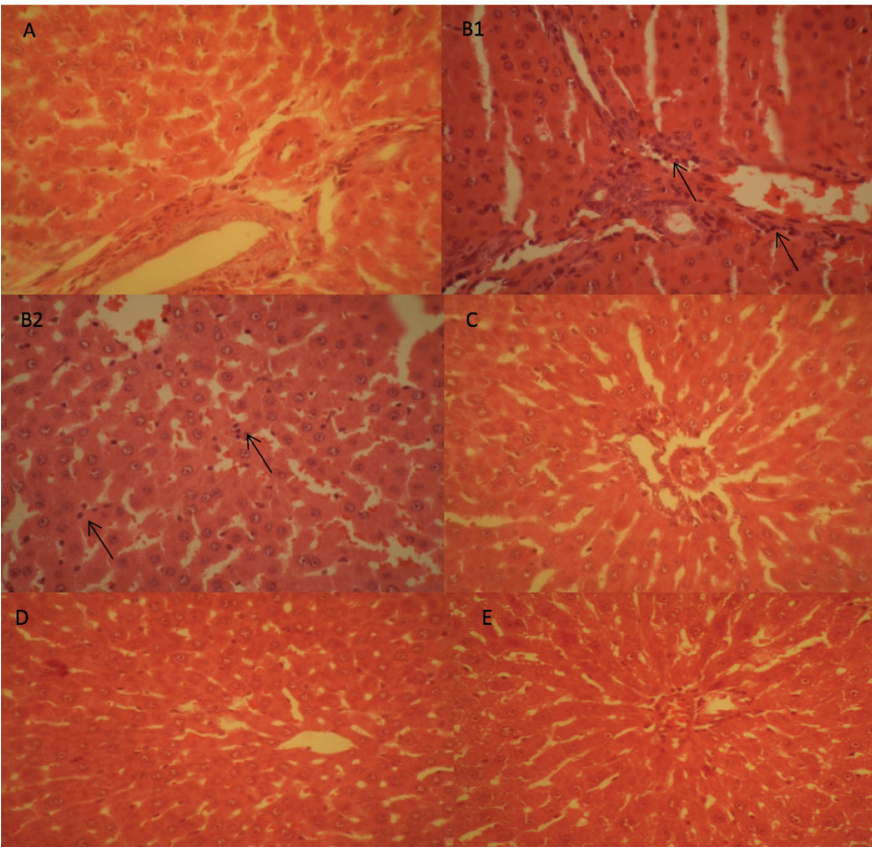

Figure 4. Histopathological studies. A) Control group, the portal tract and the hepatocytes in normal condition. B1) cecal ligation and puncture (CLP) group, neutrophil infiltration in the portal tract (arrows). B2) CLP group, neutrophil infiltration in the sinusoids, which can be seen easily with their dark nuclei (arrows). C) RD 50, the liver in normal condition without any neutrophil infiltration. Hematoxylin and eosin (H\&E), 400x. D) RD 100 group, the portal tract and parenchyma in normal condition without any neutrophil infiltration. H\&E, 400x. E) Indomethacin group, there is no sign of neutrophil infiltration in the portal tract or in the parenchyma. H\&E, 400x

Table 3. Effect of $R$. damascena essential oil on COX-2 expression and PGE2 level in CLP rats

\begin{tabular}{lll} 
Groups & PGE2 $(\mathrm{ng} / \mathrm{mL})$ & COX-2 expression $\left(\log _{10}\right)$ \\
\hline Control & $508 \pm 26.7$ & $0 \pm 0.03$ \\
\hline CLP & $796 \pm 20.7^{*}$ & $0.43 \pm 0.05^{\star}$ \\
\hline RD50 & $632 \pm 23.9^{* *}$ & $0.21 \pm 0.03^{* *}$ \\
\hline RD100 & $531 \pm 8.2^{* *}$ & $0.25 \pm 0.04^{* *}$ \\
\hline IND & $536 \pm 32.8^{* *}$ & $0.15 \pm 0.01^{* *}$ \\
\hline
\end{tabular}

${ }^{*} p<0.05$ is considered significant between the control group and cecal ligation and puncture group. ${ }^{* *} p<0.05$ is considered significant between the cecal ligation and puncture group and treated groups. Data are presented as mean \pm standard deviation

CLP: Cecal ligation and puncture, IND: Indomethacin levels of these markers were decreased ( $p<0.05)$. Meanwhile, plasma ALP and total bilirubin had no considerable differences during the experiment in all groups (Figures $3 \mathrm{C}$ and $\mathrm{D}$ ).

\section{Histological findings}

Histopathologic assessment of the liver specimens revealed that there were some mild changes consisting of congestion and granular degeneration of the hepatocytes in the control group (Figure 4A), whereas severe congestion, interstitial edema, and margination of neutrophils in the venules and sinusoids were observed in the CLP group. Neutrophils and mononuclear cells were also infiltrated in the portal tracts and sinusoids in the septic group. Kupffer cell hyperplasia and granular degeneration were the other observed changes in the CLP group. There were no signs of necrosis in hepatocytes. All the changes in the CLP group revealed a kind of hepatitis called nonspecific reactive hepatitis (Figures $4 \mathrm{~B} 1$ and $\mathrm{B} 2$ ). However, the essential oil treatments obviously reduced neutrophil infiltration in the portal tract and parenchyma of the liver tissues (Figures $4 \mathrm{C}$ and D). In addition, in the indomethacin group, there was no sign of neutrophil infiltration in the portal tract or in the parenchyma (Figure 4E).

As shown in Table 4, the CLP group obviously showed neutrophil margination and infiltration, mononuclear cell infiltration, and Kupffer cell hyperplasia as compared with the control group ( $p \leq 0.05$ ). Concerning portal inflammation, it was also meaningful in the CLP group in comparison with the control group ( $p \leq 0.05)$. However, there were no obvious difference regarding granular degeneration and inflammatory foci between all the study groups ( $p>0.05$ ). To confirm the results seen in Figure 4, all the treatment groups had prominently reduced neutrophil margination and infiltration, mononuclear cells infiltration, Kupffer cell hyperplasia, and portal inflammation in comparison with the CLP group $(p \leq 0.05)$.

\section{DISCUSSION}

Sepsis is a generalized inflammatory response of different parasites and their toxins in the body and can be regarded as a main part of the systemic inflammatory response system. Nowadays, sepsis is the major causes of death in intensive care units. The importance of sepsis in terms of mortality and morbidity and treatment difficulties makes it a public health concern. ${ }^{26}$ Oxidative stress can define an incongruence between Table 4. Mean values and standard error of histopathologic variables of the liver specimens in the study groups

\begin{tabular}{llllll} 
Study groups & $\begin{array}{l}\text { Neutrophil margination and } \\
\text { infiltration }\end{array}$ & Granular degeneration & Inflammatory foci & $\begin{array}{l}\text { Mononuclear cells infiltration \& Portal inflammation } \\
\text { Kupffer cell hyperplasia }\end{array}$ \\
\hline Control & $0 \pm 0$ & $0.4 \pm 0.24$ & $0 \pm 0$ & $0 \pm 0$ & $0 \pm 0$ \\
\hline CLP & $2.75 \pm 0.25^{*}$ & $0.75 \pm 0.75$ & $1.5 \pm 0.86$ & $3 \pm 0.4^{*}$ & $2.25 \pm 0.25^{*}$ \\
\hline RD50 & $1.4 \pm 0.24^{* *}$ & $0.2 \pm 0.2$ & $0.2 \pm 0.2$ & $1.2 \pm 0.2^{* *}$ & $0.6 \pm 0.24^{* \star}$ \\
\hline RD100 & $0.8 \pm 0.2^{* *}$ & $0.2 \pm 0.2$ & $0 \pm 0$ & $1.6 \pm 0.24^{* *}$ & $1 \pm 0^{\star *}$ \\
\hline IND & $0.5 \pm 0.28^{* *}$ & $0 \pm 0$ & $0 \pm 0$ & $1 \pm 0^{* *}$ & $0.25 \pm 0.25^{\star *}$ \\
\hline
\end{tabular}

*: Having significant difference in comparison with the control group, **: Having significant difference in comparison with the cecal ligation and puncture group CLP: Cecal ligation and puncture, IND: Indomethacin 
oxidants and the body's antioxidant system. ${ }^{27}$ It can activate immune systems that promote a destructive effect on lipid, protein, and DNA. The antioxidant defense system can confront sepsis and its consequences by combating free radicals. The role of antioxidant agents in treating sepsis was proved by different studies. Therefore, in the current study, the antioxidant and hepatoprotective activities of $R$. damascena essential oils were investigated, for the first time, through assessing the main antioxidant/oxidative stress and anti-inflammatory parameters. In the present study, the levels of ALT, AST, MPO, and MDA as well as $\mathrm{PGE}_{2}$ and COX-2 expression ( $p<0.05$ ) significantly rose FRAP and GSH levels ( $p<0.05$ ) fell in the septic rats (Tables 2 and 3 and Figure 3 ), but they were modulated the $R$. damascene essential oils.

Polymorphonuclear leukocyte infiltration following systemic inflammatory response could be created during sepsis, which can result in vascular as well as parenchymal cell dysfunctions. Leucocyte aggregation and activated neutrophils leading to tissue injuries were increased due to the rise of ROS elements. Activated neutrophils can cause MPO secretion and free radical production, ${ }^{28}$ meaning the MPO assay is a valuable indicator to evaluate neutrophil accumulation and severity of inflammation in sepsis, which was reversed in rats treated with antioxidative $R$. damascena essential oils (50 and $100 \mathrm{mg} / \mathrm{kg}$ bw) ( $p<0.05$ ) (Table 2). Our results were in agreement with other studies, which showed that MPO activity as neutrophil accumulations was elevated by sepsis, while pretreatment with selenium, $n$-acetylcysteine, and simvastatin decreased MPO activity by scavenging free radical generation, which suppressed the severity of sepsis. ${ }^{10,29,30}$

One of the consequences of sepsis is an event called lipid peroxidation, which is considered as the main oxidative stress parameter and which was increased by the impact of free radicals and MPO increment. ${ }^{10}$ Lipid peroxidation can cause cell and mitochondria damage, which initiate protein degeneration, cell lysis, and necrosis. ${ }^{31}$ Treatment of rats with the essential oils decreased $(p<0.05)$ lipid peroxidation, which eventually resulted in diminishing MDA level (Table 2). Our results were confirmed by, Ozdulger et al. ${ }^{32}$ who reported that MPO activity and MDA concentration were increased in the lungs by sepsis, which showed the intensity of neutrophil infiltration and oxidative stress in rats. Applying estrogen could diminish MDA concentration and as a result of decreasing lipid peroxidation, which protected the ileum and liver from the sepsis-induced and oxidative stress condition.

It is thought that there is a direct link between lipid peroxidation and GSH depletion in sepsis. GSH is considered an important natural antioxidant system that can deal with ROS production by neutralizing them. By establishing the oxidative stress condition in the body, ROS changed the antioxidant power. In other words, the antioxidant defense system in the body was compromised, leading to increased lipid peroxidation concomitant with changes in GSH and antioxidant enzymes such as GST, CAT, and SOD..$^{33}$ In our study, we observed that CLP induction caused a decrease in GSH level in comparison to the control group ( $p<0.05$, Table 2).
On the contrary, treatment rats with $R$. damascena essential oil restored the level of GSH in ideal concentration ( $p<0.05$ ), indicated that inhibiting GSH depletion has curative efficiency that increases the defense ability system, which protects the body from oxidative stress by preventing lipid peroxidation. Our results are in agreement with those published by Bouzenna et al. ${ }^{34}$ who reported that the administration of Citrus limon essential oil had a hepatoprotective effect on the oxidative stress caused by aspirin as revealed by decreasing lipid peroxidation and amplifying the antioxidant defense system (GSH, CAT, and GPx). Moreover, the present study revealed a significant decline in FRAP in sepsis, while administration of the essential oils caused a significant increase $(p<0.05)$ in the plasma FRAP (Table 2). A decrease in FRAP levels, as a factor in oxidative stress/antioxidant balancing, led to increase resistance and/or decreased susceptibility of the liver to free radical attack. ${ }^{35} \mathrm{On}$ the contrary, GST activities in the liver did not change ( $p>0.05)$ in the treated groups (Table 2), which indicated no probable effective role of this enzyme in the detoxification of septic rats.

On the other hand, in sepsis, changes in cytokine levels were clearly seen, showing the imbalances between proinflammatory and anti-inflammatory cytokines. ${ }^{36}$ It seems that expression of COX-2 increased by pro-inflammatory cytokines, which simulate $\mathrm{PGE}_{2}$ level (Table 3). COX-2 is an enzyme that could simulate production of prostaglandins like $\mathrm{PGE}_{2}$, which can initiate oxidative damage in tissue. ${ }^{37}$ Increases in COX2 expression stimulated the production of $\mathrm{PGE}_{2}$, resulting in increases in its plasma level. In other words, COX-2 expression is the key principle to immunologic disharmony in septic rats, and so ceasing the COX-2 expression diminishes the effect of oxidative stress.$^{38}$ In our study, the treatment of rats with $R$. damascena essential oils had an inhibitory effect on the production of cytokines and ROS, leading to decreased COX2 expression together with plasma $\mathrm{PGE}_{2}$ level. Huang et al. ${ }^{37}$ reported that LPS has a negative effect on COX-2 expression and $P G E_{2}$ production. LPS significantly increased $P G E_{2}$ levels and COX-2 transcription and also production of tumor necrosis factor- $\alpha$, interleukin (IL)-1 $\beta, I L-6$, and IL-10. They proved that Bupivacaine significantly decreases COX-2 expression and PGE2 and cytokine production.

In addition, the plasma levels of ALT and AST, which are considered the most important biomarkers of liver enzymes, could be considerably elevated by hepatocellular injuries. ${ }^{39}$ Hepatic injuries are characterized by irregular biomarkers of liver that can be confirmed by elevations in AST and ALT levels. Elevations in the concentrations of these enzymes indicated loss of integrity of the liver, apoptosis, and necrosis. Due to the induction of CLP, the concentrations of these enzymes increased compared to the control group ( $p<0.05$, Figures $3 A$ and B). Liver injuries in the pathologic study confirmed these changes (Figure 4). After hepatic injuries, these enzymes released by cellular necrosis and the elevation of these enzymes showed the rate of damage on integrity of the liver. Treatment of rats with $R$. damascena essential oils as well as indomethacin had ability to reduce hepatoinjuries by diminishing these biomarkers (Table 4 and Figures 3 and 4 ). 
On the other hand, ALP is related to injuries in the bile duct and integrity of the cell membrane. Total bilirubin is also considered a parameter of liver injuries. ${ }^{39}$ In the present study, there was no difference in the serum level of ALP and total bilirubin did not differ between the CLP-induction group and the other groups ( $p<0.05$, Figures $3 C$ and D), indicating that CLP does not cause considerable damage to the liver or biliary ducts.

The present study indicated a significant relationship between in vitro antioxidative effects of $R$. damascena essential oils and in vivo anti-inflammatory effects. Citronellol (66.11\%), trans geraniol (11.56\%), and phenylethyl alcohol (5.33\%) are the main constituents of the essential oils (Table 1), which possessed antioxidant activities proved by DPPH and $\beta$-carotene/linoleic acid bleaching assays. According to recent studies, these components are completely related to the antioxidant and radical scavenging ability of the essential oil as it was reported that fresh juice of $R$. damascena has antioxidant potential against rats that received $\mathrm{CCl}_{4}$ as a toxic material that can cause hepatoinjuries. ${ }^{18}$

\section{CONCLUSION}

This study confirmed that $R$. damascena essential oils had antioxidative and hepatoprotective effects against CLP-induced sepsis caused by reactive species. The essential oils decreased oxidative stress parameters, improving the antioxidant defense system, and restoring the ideal concentration of inflammatory parameters and it was confirmed by histopathology assessment.

\section{ACKNOWLEDGEMENTS}

This research was conducted by the Research Deputy Grand of Qom Branch, Islam Azad University.

Conflict of Interest: No conflict of interest was declared by the authors.

\section{REFERENCES}

1. Angus DC, van der Poll T. Severe sepsis and septic shock. N Engl J Med. 2013;369:840-851.

2. Peters K, Unger RE, Brunner J, Kirkpatrick CJ. Molecular basis of endothelial dysfunction in sepsis. Cardiovasc Res. 2003;60:49-57.

3. Peters J, Cohen J. Sepsis. Med J. 2013;41:667-669.

4. Cho SY, Choi JH. Biomarkers of sepsis. Infect Chemother. 2014;46:112.

5. Nelson GE, Mave V, Gupta A. Biomarkers for sepsis: A review with special attention to India. Biomed Res Int. 2014;2014:264351.

6. Li S, Zhu FX, Zhao XJ, An YZ. The immunoprotective activity of interleukin-33 in a mouse model of cecal ligation and punctureinduced sepsis. Immunol Lett. 2016;169:1-7.

7. Koh HJ, Joo J, Cho ML, Her YM, Hwang JE, Lee J. Proinflammatory and anti-inflammatory cytokine balance in patients with cirrhotic hepatitis during live-donor liver transplant. Exp Clin Transplant. 2013;11:39-43.

8. Lowes DA, Webster NR, Murphy MP, Galley HF. Antioxidants that protect mitochondria reduce interleukin- 6 and oxidative stress, improve mitochondrial function, and reduce biochemical markers of organ dysfunction in a rat model of acute sepsis. $\mathrm{Br} \mathrm{J}$ Anaesth. 2013;110:472-480.

9. Dejager L, Pinheiro I, Dejonckheere E, Libert C. Cecal ligation and puncture: the gold standard model for polymicrobial sepsis? Trends Microbiol. 2011;19:198-208.

10. Song $T$, Yin $H$, Chen J, Huang L, Jiang J, He T, Huang $H, H u X$. Survival advantage depends on cecal volume rather than cecal length in a mouse model of cecal ligation and puncture. J Surg Res. 2016;203:476-482.

11. Schabbauer G. Polymicrobial sepsis models: CLP versus CASP. Drug Discov Today Dis Models. 2012;9:17-21.

12. Cuenca AG, Delano MJ, Kelly-Scumpia KM, Moldawer LL, Efron PA. Cecal ligation and puncture. Curr Protoc Immunol. 2010;91:19.13.119.13.11.

13. Hajhashemi V, Ghannadi A, Hajiloo M. Analgesic and antiinflammatory effects of Rosa damascena hydroalcoholic extract and its essential oil in animal models. Iran J Pharm Res. 2010;9:163-168.

14. Mahboubi M. Rosa damascena as holy ancient herb with novel applications. J Tradit Complement Med. 2015;6:10-16.

15. Dolati K, Rakhshandeh H, Shafei MN. Antidepressant-like effect of aqueous extract from Rosa damascena in mice. Avicenna $J$ Phytomed. 2011;1:91-97.

16. Akbari M, Kazerani HR, Kamrani A, Mohri M. A preliminary study on some potential toxic effects of Rosa damascena Mill. Iran J Vet Res. 2013;14:232-236.

17. Gholamhoseinian A, Fallah $H$, Sharifi far F. Inhibitory effect of methanol extract of Rosa damascena Mill. flowers on D-glucosidase activity and postprandial hyperglycemia in normal and diabetic rats. Phytomedicine. 2009;16:935-941.

18. Achuthan CR, Babu BH. Padikkala J. Antioxidant and hepatoprotective effects of Rosa damascena. Pharm Biol. 2003;41:357-361.

19. Baydar NG, Baydar H. Phenolic compounds, antiradical activity and antioxidant capacity of oil-bearing rose (Rosa damascena Mill.) extracts. Ind Crops Prod. 2013;41:375-380.

20. Yassa N, Masoomi F, Rohani Rankouhi SE, Hadjiakhoondi A. Chemical composition and antioxidant activity of the extract and essential oil of Rosa damascena from Iran, population of Guilan. DARU J Pharm Sci. 2009;17:175-180.

21. Sedlak J, Lindsay RH. Estimation of total, protein-bound, and nonprotein sulfhydryl groups in tissue with Ellman's reagent. Anal Biochem. 1968;25:192-205.

22. Hillegass LM, Griswold DE, Brickson B, Albrightson-Winslow C. Assessment of myeloperoxidase activity in whole rat kidney. J Pharmacol Methods. 1990;24:285-295.

23. Buege JA, Aust SD. Microsomal lipid peroxidation. Methods Enzymol. 1978;52:302-310.

24. Habig WH, Pabst MJ, Jakoby WB. Glutathione S-transferases. The first enzymatic step in mercapturic acid formation. J Biol Chem. 1974:249:7130-7139.

25. Benzie IF, Strain JJ. The ferric reducing ability of plasma (FRAP) as a measure of "antioxidant power": the FRAP assay. Anal Biochem. 1996;239:70-76.

26. Zolali E, Hamishehkar H, Maleki-Dizaji N, Majidi Zolbanin N, Ghavimi $H$, Kouhsoltani M, Asgharian P. Selenium effect on oxidative stress factors in septic rats. Adv Pharm Bull. 2014;4:289-293. 
27. Abd El Tawab AM, Shahin NN, AbdelMohsen MM. Protective effect of Satureja montana extract on cyclophosphamide-induced testicular injury in rats. Chem Biol Interact. 2014;224:196-205.

28 Makled MN, El-Awady MS, Abdelaziz RR, Atwan N, Guns ET, Gameil NM, Shehab El-Din AB, Ammar EM. Pomegranate protects liver against cecal ligation and puncture-induced oxidative stress and inflammation in rats through TLR4/NF-B pathway inhibition. Environ Toxicol Pharmacol. 2016;43:182-192.

29. Cuzzocrea S, Mazzon E, Dugo L, Serraino I, Ciccolo A, Centorrino T, De Sarro A, Caputi AP. Protective effects of $n$-acetylcysteine on lung injury and red blood cell modification induced by carrageenan in the rat. FASEB J. 2001;15:1187-1200.

30. Mohamadin AM, Elberry AA, Abdel Gawad HS, Morsy GM, AlAbbasi FA. Protective effects of simvastatin, a lipid-lowering agent, against oxidative damage in experimental diabetic rats. J Lipids. 2011;2011:167958.

31. Sener G, Arbak S, Kurtaran P, Gedik N, Yeğen BC. Estrogen protects the liver and intestines against sepsis-induced injury in rats. J Surg Res. 2005;128:70-78.

32. Ozdulger A, Cinel I, Koksel O, Cinel L, Avlan D, Unlu A, Okcu H, Dikmengil M, Oral $U$. The protective effect of $\mathrm{N}$-acetylcysteine on apoptotic lung injury in cecal ligation and puncture-induced sepsis model. Shock. 2003;19:366-372.

33. Zhong W, Qian K, Xiong J, Ma K, Wang A, Zou Y. Curcumin alleviates lipopolysaccharide-induced sepsis and liver failure by suppression of oxidative stress-related inflammation via PI3K/AKT and NF-kB related signaling. Biomed Pharmacother. 2016;83:302-313.

34. Bouzenna H, Dhibi S, Samout N, Rjeibi I, Talarmin H, Elfeki A, Hfaiedh $N$. The protective effect of Citrus limon essential oil on hepatotoxicity and nephrotoxicity induced by aspirin in rats. Biomed Pharmacother. 2016;83:1327-1334.

35. Dadkhah A, Fatemi F, Kazemnejad S, Rasmi Y, Ashrafi-Helan J, Allameh A. Differential effects of acetaminophen on enzymatic and non-enzymatic antioxidant factors and plasma total antioxidant capacity in developing and adult rats. Mol Cell Biochem. 2006;281:145-152.

36. Frencken JF, van Vught LA, Peelen LM, Ong DSY, Klein Klouwenberg PMC, Horn J, Bonten MJM, van der Poll T, Cremer OL; MARS Consortium. An unbalanced inflammatory cytokine response is not associated with mortality following sepsis: A prospective cohort study. Crit Care Med. 2017;45:e493-e499.

37. Huang YH, Tsai PS, Huang CJ. Bupivacaine inhibits COX-2 expression, PGE2, and cytokine production in endotoxin-activated macrophages. Acta Anaesthesiol Scand. 2008;52:530-535.

38. Li B, Li YM, Li X, Shi B, He MY, Zhu XL, Zhou WC, Wachtel MS, Frezza E. COX-2 inhibition improves immune system homeostasis and decreases liver damage in septic rats. J Surg Res. 2009;157:43-47.

39. Hussein RRS, Soliman RH, Abdelhaleem Ali AM, Tawfeik MH, Abdelrahim MEA. Effect of antiepileptic drugs on liver enzymes. Beni-Seuf Univ J Appl Sci. 2013;2:14-19. 